\title{
Populist constitutionalism and constituent power
}

\author{
Oran Doyle*
}

(Received 17 December 2018; accepted 20 January 2019)

\begin{abstract}
Constituent power is a helpful component of constitutional theory because it provides a conceptual and potentially normative explanation of how a new constitution can be made without any existing legal authority to do so. Contemporary theories of constituent power, however, unhelpfully treat constituent power as a fictive entity, typically the people, that subsists through time. This predominant account of constituent power fails adequately to explain examples of constitution-making and also lends support to the populist claim that a unitary and unchanging people has an immanent but continuing role as a constitutional actor superior to the constitution itself. This enables populist leaders to rely on prevalent understandings of constitutionalism to support the sidestepping and/or removal of constraints on their power. In this Article, I trace the connections between mainstream theories of constituent power and the academically peripheral claims of populist constitutionalism. I argue for a different understanding of constituent power as a capacity that, in principle, may momentarily be exercised by any entity. This explains how a new constitution can unlawfully replace a pre-existing constitution yet come to have lawful authority itself, without implying the diachronic existence of the constituent power as an entity. I illustrate this understanding of constituent power with reference to the constitutional development of Taiwan and Ireland. These examples show — contrary to the predominant account of constituent power- that constitutional systems may be created without the exercise of constituent power and that constitutional law can play an important role in constructing an entity capable of exercising constituent power. Seen in this way, popular references in preambles are important not for their account of how a constitution was made but rather for their account of whom a constitution is for. This account of constituent power undermines core claims of populist constitutionalism. But it also provides a salutary lesson for liberal constitutionalists: a constitution adopted for a people must broadly serve the interests of that people.
\end{abstract}

Keywords: populism; constitutionalism; constituent power; Carl Schmitt

\section{A. Introduction}

Populist movements are often seen as posing a threat to constitutional democracy, understood as the moral value of electorally accountable but legally constrained government. Constitutional checks and balances impede both the expression and the implementation of popular will, making them a prime target for populist dissatisfaction. Constitutional standards are managed by a legal and political elite that stands in putative opposition to the pure people, the will of whom the populist leader channels. There is thus a strong association between populism and the dismantling

\footnotetext{
${ }^{\star}$ Oran Doyle is an associate professor, Trinity College Dublin. Earlier drafts of this paper were presented at a Law Faculty Research Workshop in Trinity College Dublin on October 4, 2017, a symposium in the Law Faculty of the University of Padua on November 17, 2017, the World Congress of Taiwan Studies at the Academia Sinica in Taipei on September 6, 2018 and a workshop of the Irish Jurisprudence Society on October 18, 2018. The author is grateful to all who commented in the various forums, to the editors for their suggestions, and to Tom McMorrow, Zoran Oklopcic, and Tim Murphy who kindly provided written comments on an earlier draft. Email: Oran.Doyle@tcd.ie.
}

(C) 2019 The Author. Published by Cambridge University Press on behalf of the German Law Journal. This is an Open Access article, distributed under the terms of the Creative Commons Attribution licence (http://creativecommons.org/licenses/by/4.0/), which permits unrestricted re-use, distribution, and reproduction in any medium, provided the original work is properly cited. 
of constitutional constraints. ${ }^{1}$ Yet in other ways, constitutional democracy may lend support to populism. Many constitutions appear to invoke a unitary people in their preambles, recording the fact that they are made by and for a particular people. This reflects, or is reflected by, a prevalent constitutional theory that holds that the people is the constituent power, at all times subsisting the constitutional order. Constitutional rhetoric and mainstream constitutional theory therefore both lend support to the populist claim that a unitary and unchanging people has an immanent but continuing role as a constitutional actor superior to the constitution itself. This enables populist leaders to rely on prevalent understandings of constitutionalism to support the sidestepping and/ or removal of constraints on their power.

In this Article, I trace the connections between mainstream theories of constituent power and the academically peripheral claims of populist constitutionalism. Constituent power is a helpful component of constitutional theory because it provides a conceptual and potentially normative explanation of how a new constitution can be made without any existing legal authority to do so. Contemporary theories of constituent power, however, unhelpfully treat constituent power as a fictive entity, typically the people, that subsists through time. In a slight variation of this, some theories hold that the constituent power is a capacity that can only, at least in contemporary times, be exercised by the people. This predominant account of constituent power fails adequately to explain examples of constitution-making and leads us into a conceptual morass.

In this Article, I argue for a different understanding of constituent power as a component of constitutional theory. Understood as a capacity that, in principle, may momentarily be exercised by any entity, constituent power theory explains how a new constitution can unlawfully replace a pre-existing constitution yet come to have lawful authority itself, without implying the diachronic existence of the constituent power as an entity. This also identifies the sort of normative argument necessary to justify legally unauthorized acts of constitution-making. I illustrate this understanding of constituent power with reference to the constitutional development of Taiwan and Ireland. These examples show-contrary to the predominant account of constituent power-that constitutional systems may be created without the exercise of constituent power and that constitutional law can play an important role in constructing an entity capable of exercising constituent power. Seen in this way, popular references in preambles are important not for their account of how a constitution was made but rather for their account of whom a constitution is for. This account of constituent power, which is both conceptually and descriptively more attractive than the predominant account that treats constituent power as an entity (or a capacity necessarily borne by the people), undermines core claims of populist constitutionalism. But it also provides a salutary lesson for liberal constitutionalists: a constitution adopted for a people must broadly serve the interests of that people.

\section{B. Constituent power and popular sovereignty}

During the French revolution, Emmanuel Joseph Sieyès invoked a distinction between constituent power and constituted power in order to justify the power of the "nation" over the king. ${ }^{2}$ Carl Schmitt subsequently generalized this distinction between constituent (or constitution-making) power and constituted power into a constitutional theory. ${ }^{3}$ Constituent power relates to the entity that creates the constitution, constituted powers are all those powers created by the constitution itself. Whereas the constituent power is unfettered by any legal or moral constraint, constituted powers are-according to Schmitt—necessarily constrained. An important implication of this for

\footnotetext{
${ }^{1}$ See David Landau, Populist Constitutions, 85 U. CHI. L. Rev. 521 (2018); Samuel Issacharoff, Populism Versus Democratic Governance, in Constitutional Democracy in Crisis 445 (Mark A. Graber, Sanford Levinson \& Mark Tushnet eds., 2018).

${ }^{2}$ Thomas Pereira, Constituting the Amendment Power, in The Foundations and Traditions of Constitutional AmEndment 105 (Richard Albert, Xenophon Contiades \& Alkmene Fotiadou eds., 2017).

${ }^{3}$ CARl Schmitt, Constitutional Theory (Jeffrey Seitzer trans., 2008).
} 
Schmitt, to which we shall return later, concerns constitutional amendment: as the amendment power is constituted, it cannot be exercised in a way that erodes the identity and continuity of the constitution as an entirety. ${ }^{4}$

In contemporary constitutional theory, there is a strong association between constituent power and popular sovereignty: the people are assumed either to be or to bear the constituent power. Luigi Corrias, presents a populist reading of constituent power stating, "The notion of constituent power refers to the authority to make the constitution and thus to institute the legal order. It belongs to the people. As constituent power, the people is understood to already exist prior to and independent of the constitutional order." 5

Joel I Colón-Ríos advances a democratic theory of constitutionalism based on an analysis of constituent power. ${ }^{6}$ He argues that not just the ordinary workings of the constitution but also its manner of creation and alteration should be democratic. In particular, he maintains that the constituent power of the people should be allowed to reemerge to challenge an existing constitutional order. He builds this argument on Schmitt's theory of constituent power, describing constituent power as "par excellence a democratic concept." ${ }^{7}$ He presents the following democratic account of constitution-making power:

Constituent power... has an important connection with the democratic ideal. In its modern and contemporary foundations, constituent power is attributed to the nation, the people or the community; in short, to all those who will become subject to the future constitutional regime. Constituent power points toward a democratic constitution-making power, and its popular and collective character makes it incompatible with given or imposed constitutions. ${ }^{8}$

This account of the people's role in constitution-making is consistent with how many constitutions present their own origins, although it is unclear whether the constitutions reflect the theory or the theory reflects the constitutions. Constitutional texts, adopted during different waves of constitution-making and in different regions as the following cursory examination suggests, describe their own foundation in a way that posits or assumes an extraconstitutional entity that made the constitution. The preamble to the 1788 U.S. Constitution provides, "We the People of the United States . . . do ordain and establish this Constitution for the United States of America." The preamble to the 1853 Argentine Constitution provides, "We, the representatives of the people of the Argentine Nation . . . do ordain, decree and establish this Constitution for the Argentine Nation." The preamble to the 1949 German Constitution provides, "[T]he German people, in the exercise of their constituent power, have adopted this Basic Law. This Basic Law thus applies to the entire German people." The preamble to the 1992 Constitution of Uzbekistan provides, "The people of Uzbekistan ... adopt in the person of their plenipotentiary representatives the present Constitution of the Republic of Uzbekistan." The preamble to the 2008 Constitution of Angola provides, "We, the people of Angola, through its lawful representatives, the legislators of the nation... hereby pass this Constitution as the Supreme and Fundamental Law of the Republic of Angola." At the core of contemporary constitutionalism, therefore, lies a fundamental role for the people. The claim that the people necessarily is the constituent power provides a ready conceptualization of this phenomenon. In parts D and E, I shall argue that this claim is flawed. Before doing so, however, I shall explore its connections with populism.

\footnotetext{
${ }^{4}$ Id. at 150.

${ }^{5}$ L.D.A. Corrias, Populism in a Constitutional Key: Constituent Power, Popular Sovereignty and Constitutional Identity, 12 E.U. Const. L. Rev. 6, 10 (2016).

${ }^{6}$ Joel I. Colón Ríos, Weak Constitutionalism: Democratic Legitimacy and the Question of Constituent Power (2012).

${ }^{7}$ SCHMITT, supra note 3 , at 95 .

${ }^{8} I d$. at 102 .
} 


\section{Populism and populist constitutionalism}

The suggestion of a populist constitutionalism is apt to raise heckles. Gábor Halmai contends that populist constitutionalism is an oxymoron: there can be populist constitutions, but there cannot be populist constitutionalism, because the values of populism are antithetical to the values of constitutionalism. ${ }^{9}$ This approach insists on an understanding of constitutionalism as a moral value. This is a valid position within political thought, the most focused and distinctive claim being that constitutionalism connotes the value of constrained government. ${ }^{10}$ Constitutionalism, however, is often used in a more neutral way to capture simply the practice of government under a constitution, which allows it to be juxtaposed with almost any adjective. ${ }^{11}$ Analytical clarity would surely be assisted if "constitutionalism" had only one meaning, but I fear that linguistic horse has bolted. Both understandings of constitutionalism have achieved currency, such that neither is inappropriate. We must be alert, however, to their differences. If we understand constitutionalism as simply the practice of government under a constitution, populist constitutionalism is not a contradiction. Rather, it is a theory of constitutions and constitutional practices that emphasizes their populist character and recommends that they develop along a populist trajectory. It presents and justifies populist claims with reference to more widely accepted accounts of the popular role in constitutions, principally the theory of constituent power.

There is much debate in the academic literature as to the meaning of "populism," and indeed as to whether populism has a sufficiently fixed meaning for it to qualify as a useful concept in academic analysis. Within general discourse, the label populist is applied to a bewildering array of political figures and movements, from Donald Trump and Bernie Sanders in the United States, to Hugo Chávez in Venezuela and Victor Orbán in Hungary. If anything unifies these political figures, it is not their political ideology. Nevertheless, it has been convincingly argued that populism retains a coherent core of ideas, notwithstanding the different ideological valence of self-described or ascribed populists. Mudde and Kaltwasser adopt what they term an ideational approach, defining populism as "a thin-centered ideology that considers society to be ultimately separated into two homogeneous and antagonistic camps, 'the pure people' versus the 'corrupt elite,' and which argues that politics should be an expression of the volonté générale (general will) of the people." 12 They note three understandings of the people in this account: as sovereign, as the common people, and as the nation. ${ }^{13}$

In a similar vein, Jan-Werner Müller argues that populism is a particular moralistic imagination of politics. It sets a "morally pure and fully unified ... people against elites who are deemed corrupt or in some other way morally inferior." ${ }^{14}$ Populists are also anti-pluralist and believe that only they can represent this pure people. ${ }^{15}$ Müller identifies broadly the same three senses of people as do Mudde and Kaltwasser: the body politic, the common people, and the nation. ${ }^{16}$ The notion of a pure and unified people may be a fiction but it provides the ideological core of populism. Margaret Canovan characterizes populism as a reaction against existing power structures that claims legitimacy through its appeal to the sovereign people. She identifies three different, but often overlapping, senses of the people in these invocations: the united people (the nation as against the parties and factions that divide it), the ethnically homogeneous nation, and the common people. ${ }^{17}$ In earlier

\footnotetext{
${ }^{9}$ Gábor Halmai, Populism, Authoritarianism And Constitutionalism, 20(3) Germ. L.J. (2019), forthcoming.

${ }^{10}$ Will Waluchow, Constitutionalism, in The Stanford Encyclopedia of Philosophy, (Edward N. Zalta, ed., Spring 2019 ed.) https://plato.stanford.edu/archives/spr2018/entries/constitutionalism/.

${ }^{11}$ For examples of such usages, see David Landau, Abusive Constitutionalism, 47 U. C. DAvis L. REv. 189 (2013); Mark Tushnet, Authoritarian Constitutionalism, 100 CoRnell L. Rev. 391 (2015).

${ }^{12}$ Cas Mudde \& Crisóbal Rovira Kaltwasser, Populism: A Very Short Introduction 5 (2017).

${ }^{13} I d$. at 9 .

${ }^{14}$ Jan-Werner Müller, What is Populism 19 (2016).

${ }^{15} \mathrm{Id}$.

${ }^{16} I d$. at 22.

${ }^{17}$ Margaret Canovan, Trust the People! Populism and the Two Faces of Democracy, 47 Pol. STUD. 2, 4-5 (1999).
} 
work, she notes how populist argumentation can slide between invocation of the whole people and invocation of the common people as the underdog against an elite. ${ }^{18}$

All of these accounts treat populism as a distinctive mode of political argumentation that can be put in service of a wide range of ideological positions. Populists can invoke and slide between different understandings of the people in arguing for greater redistribution, controls on immigration, traditional moral values, and rejection of expertise and technocratic approaches to governance. One of the possible targets of populist argumentation is constitutional democracy itself. Mudde and Kaltwasser suggest that populism is essentially democratic but at odds with liberal democracy. ${ }^{19}$ Cesare Pinelli has argued that while populists are unlikely to question representative democracy, "They attack non-majoritarian institutions on the ground of their lack of democratic legitimacy." 20 Popular sovereignty provides a compelling rallying cry against the complexity of modern government. Mudde and Kaltwasser note, "by claiming that no institution has the right to constrain majority rule, populist forces can end up attacking minorities and eroding those institutions that specialize in the protection of fundamental rights." 21

The core features of populist argumentation lend themselves to a critique of constitutionalism, understood as the moral value of constrained government. For it is constraints on government, whether through judicial protection of fundamental rights, the powers of technocratic central bankers, or supranational legal obligations, that trammel the people's ability to seize control of government and make it more responsive to their demands. In this vein, Corrias draws attention to how Geert Wilders argued for the Netherlands unilaterally and immediately to withdraw from the Schengen area, and how the ruling Fidesz party in Hungary has reduced the ability of the Constitutional Court to act as a counterweight to the government. ${ }^{22}$ David Landau maintains that there is a relationship between populist ideology (the divide between the pure people and the corrupt elite) and large-scale constitutional change that seeks to re-found the political and social order. ${ }^{23}$ At first, he argues, populists present improvements to the liberal constitutionalist order while subtly removing checks on their own power. In the long run, however, populists will seek to replace the liberal constitutional order, characterizing it as a dangerous hindrance to populist political projects. Importantly, populists not only target counter-majoritarian constraints but also seek to rig the electoral system so that they may retain control even when they lack majority support, the concern addressed by David Prendergast in this volume. ${ }^{24}$

In these accounts, populism is straightforwardly antithetical to constitutionalism, understood as the moral value of electorally accountable but constrained government. However, if we understand constitutionalism as connoting simply the practice of government under a constitution, we can countenance the possibility of populist constitutionalism as a coherent political theory. The theory of constituent power provides the language of constitutional justification for political populism. Drawing the connection between populism and theories of constituent power, Corrias has identified three features of such a populist constitutional theory. ${ }^{25}$ First, the people exist as a constituent power prior to and independently of the constitution: the populist therefore values the will of the people over constitutional rules. Second, populists understand popular sovereignty as the presence of the people in quotidian politics with a common interest and will: this leads to a distrust of politicians and representation, perhaps with a preference for referendums as a direct expression of the popular voice. Third, constitutional identity turns on a people with a fixed identity, traceable through time.

\footnotetext{
${ }^{18}$ Margaret Canovan, "People”, Politicians and Populism, 19 Gov’t \& Opposition 352 (1984).

${ }^{19}$ Mudde \& Kaltwasser, supra note 12 , at 81.

${ }^{20}$ Cesare Pinelli, The Populist Challenge to Constitutional Democracy, 7 E.U. Const. L. Rev. 5, 15 (2011).

${ }^{21}$ Mudde \& Kaltwasser, supra note 12 , at 84.

${ }^{22}$ Corrias, supra note 5 , at 10 .

${ }^{23}$ Landau, supra note 1 , at 522 .

${ }^{24}$ David Prendergast, The Judicial Role in Protecting Democracy from Populism, in this issue.

${ }^{25}$ Corrias, supra note 5 , at $9-14$.
} 
Corrias takes issue with each of these claims, arguing that they depend on an overly rigid distinction between constituent and constituted power. Ultimately, he argues, constituent power and constituted power depend on one another. While not necessarily disagreeing with the conclusions of Corrias, in this Article I take a different approach to the understanding of constituent power and, by extension, its relationship to constituted power. This recognizes the people as a potential and significant actor in contemporary constitutionalism, but in a way that provides little support for the claims of populist constitutionalism.

\section{Constituent power as entity: a problematic approach}

The theory of constituent power provides a conceptual account of how a constitution can be created without any prior legal authorization. The most significant exponent of the theory was probably Carl Schmitt, whose work continues to influence constitutional theorists. Within his work, however, there was an important ambiguity between treating the constituent power as a capacity that could, in principle, be exercised by any entity, and treating the constituent power as an entity that was necessarily the people. My contention in this Article is that the former account of constituent power is both preferable as a matter of constitutional theory and undercuts the basis of populist constitutionalism. I shall develop this argument based on a detailed exegesis of Schmitt and a number of contemporary works of constitutional theory that build on Schmitt's work. My purpose, however, is primarily theoretical rather than exegetical.

As we saw above, Schmitt's constitutional theory revolves around the distinction between the constitution-making power and constituted powers. A constitution is valid because it derives from the will of a constitution-making power or authority; the word "will" denotes an actually existing power as the origin of a command. ${ }^{26}$ What is important here for Schmitt is the exercise of will to bring a constitutional order into being, not the identity of the actor who exercises the will. Schmitt emphasizes that the constitution-making power need not be democratic. He refers to monarchy, aristocracy or democracy as potential forms of the state. ${ }^{27}$ In modern Europe, princely absolutism established most states. ${ }^{28}$ Although he occasionally speaks of the constitution-making power in democratic terms, ${ }^{29}$ this is as a particular example of a constitution-making power, to be set against his anti-democratic examples, rather than an assertion that all constitution-making powers must be democratic. In this vein, he also gives specific examples of non-democratic constitution-making powers. For instance, "a consequence of the monarchical principle was that the king, by virtue of the plenitude of his state power, issued a constitution." ${ }^{30}$

Schmitt's indifference to the bearer of constituent power is theoretically attractive insofar as it allows a justification of why any particular constitution is authoritative in a particular area. ${ }^{31}$ One weakness of justifying constitutions with reference to democratic approval is that it provides no answer as to why a particular people is entitled to have a constitution for itself. In contemporary constitutionalism, this question is most acute in the context of secession and territorial

\footnotetext{
${ }^{26}$ SCHMITT, supra note 3, at 64 .

${ }^{27} I d$. at 93. (later observing that dynastic legitimacy can be based on the authority of a monarch (id., at 138) and that a coup d'état or monarchical revolution can eliminate the constitution making power of the people (id., at 142)).

${ }^{28} I d$. at $99-101$.

${ }^{29} I d$. ("The constitution-making power presupposes the people as a politically existing entity. The word 'nation' denotes in a clear sense a people brought to political consciousness and capable of acting.")

${ }^{30} I d$. at 104 (emphasis original).

${ }^{31} I d$. at 104. Zoran Oklopcic has suggested to me that these references do not connote indifference on the part of Schmitt as to the bearer of constituent power, but are rather rhetorical concessions before he articulates his own theory of democratic constituent power. This may well be an accurate reading of Schmitt. My argument below, however, is that the only theoretically useful account of constituent power is one that is indifferent to the identity of who exercises constituent power. If Oklopcic's reading of Schmitt is correct, my preferred account of constituent power is even further from Schmitt's views than the rather ambiguous text suggests. But my argument stands or falls on whether it is a better account of constituent power, not whether it is a better reading of Constitutional Theory.
} 
contestation. But it challenges the political authority of all democratic states: even accepting democracy as in principle a justified form of government, why do the decisions of this particular people generate obligations for me? Schmitt's constitutional theory avoids this difficulty. Because Schmitt starts from the point of particularization (unconcerned for whether it is democratic or monarchical), he automatically has an answer to this question. The whole point is that this particular people or monarch or whatever has successfully exercised constitution-making power, willing itself into existence. ${ }^{32}$

In Section B, I presented how a prevalent strand of contemporary constitutional theory links constituent power to popular sovereignty. How has this link developed despite Schmitt's stated indifference to the identity of constituent power? The answer lies, I suggest, in a fundamental ambiguity in Schmitt's thinking that obscures his crucial insight that different entities can bear the constituent power. On the one hand, Schmitt refers to the constitution-making power as a capacity. In this vein, he refers to the "subject" or "bearer" of constitution-making power, treating the power as a capacity that is held by the entity. ${ }^{33}$ On the other hand, he contends that the constitution-making power is "the political will, whose power or authority is capable of making the concrete, comprehensive decision over the type and form of its own political existence." 34 This treats the constituent power as an entity, equivalent to the way in which we sometimes refer to "the great powers" in international relations. At times, Schmitt seems to treat constitution-making power as both a capacity and an entity within the same sentence: "The fact is a constitution is valid because it derives from a constitution-making capacity (power or authority) and is established by the will of this constitution-making power." ${ }^{35}$

Treating the constituent power as an entity rather than a capacity directs our analysis away from the moment of constitution-making and towards a search for the diachronic identity of the constituent power before, at and after the moment of constitution-making. Schmitt himself identifies the continuous presence or permanence of the constitution-making power as a consequence of his theory of constitution-making: "The constitution-making power activates itself through the act of the fundamental political decision ... [the constitution-making power] remains always present depending on the circumstances. It also stands alongside and above every constitution derived from it and any valid constitutional provision of this constitution." 36

For Schmitt, therefore, the political will that makes a constitution is not momentary but exists through time, implicitly with a stable identity. It is this focus on the identity of the constituent power (as entity) that facilitates the link between the constituent power and popular sovereignty: the people are the constituent power, not just at the moment of constitution-making but always.

This account of constituent power, however, is less than satisfactory for several reasons. First, it requires us to provide an ontology of the constituent power's existence when it is not making constitutions. As the only thing, however, that the constitution-making power can do is make constitutions, attributing an existence to it at other moments in time is deeply fraught. Its existence depends on the possibility of its unanticipated re-emergence at a moment of constitution-making. But this requires us to accept the existence of an entity without any evidence other than that a constitution was made in the past and the possibility that a constitution might unlawfully be made again in the future. An entity may have the capacity to exercise constituent power, but this does not mean that the entity becomes the constituent power. ${ }^{37}$

\footnotetext{
${ }^{32}$ In Section E, I address the question, largely avoided by Schmitt, of how the sheer fact of constitution-making can generate legitimate constitutional authority.

${ }^{33} I d$. at $75,77,97,102,104,109$, and 151.

${ }^{34} \mathrm{Id}$. at 121 .

${ }^{35} I d$. at 64 . For other similar references, see id. at 121.

${ }^{36} \mathrm{Id}$. at 140.

${ }^{37}$ This is not to argue that the people cannot be diachronic. The people can exist through time, potentially exercising many capacities that allow us to attest to their existence. But the people as constituent power is not plausibly a diachronic entity. And if it is not a diachronic entity, we have no reason to treat it as an entity at all. Rather than create a new fictive entity, we should
} 
Second, if we treat constituent power as a diachronic entity (rather than a momentarily exercised capacity), it follows that the constituent power now or in the future will be the same one as made the constitution in the past. This deprives constituent power theory of what we previously identified as one of its primary attractions, namely its ability to explain why a particular people (or king or dictator) holds constitutional authority in a particular geographical domain. Constituent power can be distinguished by its identity or by its ability (unlawfully) to create a new constitutional order. But it cannot be simultaneously distinguished by both because in some circumstances they will point in different directions. If the constituent power is an entity with a fixed identity, constituent power theory can no longer explain all acts of unlawful constitution-making. Furthermore, if the constituent power must be the people, it follows that many countries do not really have constitutions at all, despite appearances to the contrary.

Third, the emphasis on the identity of the constituent power has further implications in contemporary discussions of limitations on constitutional amendment powers. As we saw above, Schmitt holds that the constituted amendment power is necessarily limited and cannot be exercised in such a way as to undermine the identity and continuity of the constitution. This claim has much support both in the academic literature and the practices of constitutional courts. I have argued elsewhere that it is mistaken. ${ }^{38}$ Schmitt's claim that constituted authorities can only exercise the powers that they are given is not unusual. His distinctive claim is that restrictions on amendment result not from a decision of the bearer of the constitution-making power but rather "from the properly understood concept of constitutional change." ${ }^{39}$ Importantly, this is a claim of conceptual limits on the constitution-making power, not on the constituted powers. At the moment of constitution-making, the constitution-making power cannot grant a power to a constituted entity to make fundamental changes to the constitution. However, if the constitution-making power is unconstrained, how can it be precluded from granting such amendment powers? This could only be the case if the supposedly unconstrained constituent power is actually subject to constraints. This self-contradictory claim cannot stand, whether we conceive of constituent power as a capacity or entity. Adrienne Stone makes a similar point, responding to the work of Yaniv Roznai, in maintaining that restraints on the amendment power are a conceptual possibility but not a conceptual necessity. ${ }^{40}$

Much contemporary scholarship, however, assumes the correctness of Schmitt's argument that amendment powers are necessarily limited, irrespective of how broadly they are expressed. The claim that amendment powers are necessarily limited is particularly problematic if we treat the constituent power as an entity. If the authority of the constitution-making power derives from the simple fact that it is the people, then why should the people's power to amend the constitution be less than the people's power to make the constitution? In a number of constitutions, the amendment power is vested in ostensibly the same entity as enacted the constitution. For instance, the Irish Constitution was enacted by plebiscite in 1937 and can now only be amended by referendum. ${ }^{41}$ Notwithstanding that the constituent power has been subsisting since 1937 and can re-emerge to make a new constitution (under the entity reading), the Schmittian position is that

\footnotetext{
instead recognise the possibility of an already existing fictive entity, such as the people (or a charismatic autocrat), exercising constituent power. This also allows for the possibility that a different people might emerge in the future and exercise constituent power to replace the constitutional order created by this people, for instance by secession.

${ }^{38}$ Oran Doyle, Constraints on Constitutional Amendment Powers, in The Foundations And TradiTIONs OF Constitutional Amendments 73, 77-80 (Richard Albert, Xenophon Contiades, \& Alkmene Fotiadou eds., 2017).

${ }^{39}$ For a presentation of this argument, see PJ Yap, The Conundrum of Unconstitutional Constitutional Amendements, 4 Global Const. 114, 116 (2015); Yaniv Roznai, Unconstitutional Constitutional Amendments: The Migration and Success of a Constitutional Idea 61 AM. J. Comp. L. 657, 690-93 (2013).

${ }^{40}$ Adrienne Stone, Unconstitutional Constitutional Amendments: Between Contradiction and Necessity, 12(3) I.C.L. JOURNAL 357 (2018).

${ }^{41}$ Constitution of Ireland 1937 art. 46.
} 
there are certain changes that the constituent power can only make by enacting a new constitution rather than amending the existing constitution.

In his ground-breaking work on unconstitutional constitutional amendments, Yaniv Roznai grapples with an equivalent problem. For the most part, Roznai treats constituent power as a capacity rather than an entity, although without emphasizing the distinction as I have done in this Article. ${ }^{42}$ Roznai, however, makes the general claim that in the modern era, the people are the subject and holder of constituent power. ${ }^{43}$ In other words, constituent power can only be exercised by one entity, the people. This tends to blur the distinction between the capacity and entity accounts of constituent power, creating the same challenge for the claim that amendment powers are necessarily limited. If the people (and only the people) can exercise untrammeled constitution-making power, why cannot the people act to achieve the same end through the amendment power, assuming that no legal limitations have been imposed on the amendment power? To resolve this problem, Roznai adopts a characterization of amendment powers as secondary constituent powers in contradistinction to the primary constituent power. These amendment powers exist along a spectrum:

The more similar the characteristics of the secondary constituent power are to those of the democratic primary constituent power ... the less it should be bound by limitations, including those of judicial scrutiny, and vice versa. The closer it is to a regular legislative power or "governmental amendment power," the more it should be fully bound by limitations and judicial scrutiny. ${ }^{44}$

In Roznai's view, popular amendment powers attempt to imitate the re-emergence of primary constituent power and should be subject to fewer constraints. They remain limited, however, and must be subject to some constraints that would not apply to precisely the same people when exercising constitution-making power.

Roznai's solution depends on an uneasy merger of a conceptual account of constitution-making power and a normative account of popular democratic authority. Conceptually, constitutionmaking power is necessarily unlimited and constituted powers necessarily limited. Normatively, the people have authority to make a constitution. We could sequence these claims simply to say that any entity may exercise constituent power, but that popular exercises are morally preferable. Instead, however, Roznai merges the conceptual and normative to conclude that only the people can make a constitution but that the people's amendment authority is necessarily limited, albeit not as limited as amendment powers vested in other entities. But this wrongly uses normative arguments in support of a conceptual claim (only the people can make a constitution) and conceptual arguments in support of a normative claim (amendments by the people should be constrained, albeit not as constrained as amendments by other entities).

As noted above, Roznai generally treats constitution-making power as a capacity rather than an entity, but his contention, shared with many others, that only one entity (the people) can exercise that capacity blurs the distinction. If we adapt his argument for those who explicitly treat the constitution-making power as an entity, we see the further problems it creates. To the question of why the people's power to amend the constitution is necessarily less than the power of the same people to make the constitution, we are told that there is not one but three entities in question: the people, the people as primary constituent power, and the people as secondary constituent power. While these collective actors may consist of precisely the same individuals, they are different entities. This imagination of additional fictive entities to solve the problems with the account of constituent power as entity offends the principle of Occam's razor. In the next Section, I will show how we can avoid these problems by treating constituent power as a capacity.

\footnotetext{
${ }^{42}$ Yaniv Roznai, Unconstitutional Constitutional Amendments: the Limits of Amendment Powers ch. 4 (2017).

${ }^{43} I d$. at 106.

${ }^{44} I d$. at 162 .
} 


\section{E. Constituent power as capacity}

The confusion of constituent power as capacity and constituent power as entity has caused significant problems for constitutional theory. Theorists working within a Schmittian frame have tended to focus on the identity of the constituent power, creating a fictive entity that subsists through time despite there being no evidence of its existence other than at discrete moments of constitution-making. This is far from parsimonious, needlessly multiplying entities. Relatedly, theorists have tended to assume that the constituent power as an entity must be the people. There is thus a fictive people that exists through time, originally made the constitution and is the only entity empowered at any moment to set it aside. This fictive people, however, is different from the people in general and also different from the people vested with an amendment power. This constitutional theory provides support for the claims of populist constitutionalism, identified by Corrias. If we treat constituent power as a capacity rather than an entity, however, constitutional invocations of popular sovereignty relate to momentary exercises of constitution-making power rather than the diachronic existence of an unchanging people to which the constitution is beholden. A people may have exercised unconstrained constituent power to create a new constitution, but this has no implications for the constrained role of the people in amending the constitution, nor the question of who might exercise constituent power in the future.

There is a problem here, however. The capacity account of constituent power is almost tautologically true: the bearer of constituent power is that entity which succeeded in creating a constitution. How can this translate into an account of political authority in which the constitution contains norms that genuinely impose obligations? Insofar as he recognizes this question, Schmitt merges power and authority, stating that the "constitution-making power is the political will, whose power or authority is capable of making the concrete, comprehensive decision over the type and form of its own political existence." 45 In a note to the phrase "power or authority," he states that the distinction of power and authority need not be further elaborated for the continuing exposition of his constitutional theory. ${ }^{46} \mathrm{He}$ seems to equate power with something akin to might, and authority with something akin to legitimacy, but he does not explain how one can equate to or lead to the other.

This discussion is not helped by the ambiguity in the word "power," so let us distinguish between constituent might (the brute-force ability to create an effective constitution) and legitimate constituent authority (the moral ability to create a constitution that generates genuine moral obligations for those subject to it) ${ }^{47}$ We can then sketch an argument that links constitution-making might with legitimate constitutional authority. Law derives its legitimate authority from its sheer ability to coordinate human affairs in the interests of the common good. ${ }^{48}$ Constitutions play a particularly important role in this endeavor because they are critical in linking the other rules into a legal system. The common good is served not simply by individual laws resolving individual coordination problems, but rather by a system of laws that provides, or at least claims to provide, a coherent set of rules for people inhabiting a particular geographic area. But this requires that a constitution be tied to a particular geographic area. Constituent might is the factual ability to define that geographically bounded political community and create its constitution. Because the common good requires that such determinations be made, successful exercises of constituent might can transpire to have been exercises of legitimate constituent authority.

\footnotetext{
${ }^{45}$ SCHMitT, supra note 3 , at 124 (emphasis added).

${ }^{46} I d$. at $458-59$.

${ }^{47}$ Vicki Jackson draws attention to this ambiguity although disentangles power from authority in a rather different way from that suggested in this Article. Vicki Jackson, "Constituent Power" or Degrees of Legitimacy?, 12(3) I.C.L. J. 319 , 321 (2018).

${ }^{48}$ John Finnis, Natural LaW and Natural Rights ch. 10 (2d ed. 2011).
} 
Attention to the territorial dimension of constitutional systems allows us to place exercises of constituent power in their appropriate context. The brute exercise of constituent might is one way in which a geographically bounded political community can be defined, but not the only way. Where constituent might is successfully exercised, this can amount to legitimate constituent authority, conveying constitutional legitimacy on the resulting constitutional system. This does not provide a prospective authorization for all exercises of constituent might, however. If there is an existing constitutional system that reasonably performs its coordination function, thereby supporting the common good, there is at least a presumption against exercises of constituent might that could disrupt the system. Exercises of constituent might are prospectively justified only where, all things considered, the new constitution would be such an improvement on the existing constitution that it overrides the risk of ending up without any constitutional framework for the pursuit of the common good. Nevertheless, even the unjustified exercise of constituent might can result in a constitution that retrospectively acquires legitimate constitutional authority because it is now the only constitution capable of performing the coordinating function of law in that geographic area. Either way, the legitimacy of a constitutional order depends not on the question of who made it but rather on the extent to which it serves the common good of those who are subject to it.

This focus on whom the constitution is made for rather than whom the constitution is made by solves a number of other problems. It means that we need not be so concerned to distinguish between real and faux references to popular enactment. Even a constitution enacted by autocratic diktat can be a constitution for a people: its legitimacy depends on whether it serves their interests well, rather than whether they enacted it. Indeed, the claim of "we the people" is a rhetorical exaggeration even of what occurs in a plebiscite: some may have been too young to vote, others may not have voted, many will have opposed it. The falseness of this asserted univocal people need not overly trouble us, ${ }^{49}$ however, because what is relevant about constituent power is that it was exercised for them, not by them. ${ }^{50}$ If the legitimacy of a constitution depends on the fact that it was made by the people, we need an account that bridges the gap between the claim of popular enactment and the reality of how that constitution was actually enacted. In contrast, if the legitimacy of a constitution depends on how it serves the interests of those subject to it, then the claim of popular enactment can be treated simply as part of an attempt to construct the people for whom the constitution was made. Overall, this account of constituent power as capacity opens the way to new insights into the process of constitution-making, and in particular the role of popular sovereignty and preambular references to "we the people." It also fits better with actual experiences of constitution-making, shedding further light on those experiences, as I shall now explore in the next two sections.

\section{F. Taiwan: constitution without constituent power}

The Constitution of the Republic of China was approved in 1946 by a Constitutional National Assembly consisting of thousands of delegates selected in 1936 and 1937 from across China, only seventeen of whom had come from the island of Taiwan. ${ }^{51}$ Following the Civil War and the retreat of the Nationalists (KMT) under Chiang Kai-shek to Taiwan, a decision was made that the Constitution should apply to Taiwan. However, although it applied only to the island of Taiwan and its smaller offshore islands - the Chinese mainland being under the control of the

\footnotetext{
${ }^{49}$ Jackson, supra note 47 , at 322.

${ }^{50}$ This does have some implications for voting entitlements in a popular constitutional democracy. Voting rights should be based on residency or there should, at least, be a swift route to citizenship based on residency. Conversely, citizens who are no longer resident should lose their right to vote.

${ }^{51}$ From 1895 to 1945 , Taiwan was under Japanese rule. For my account of Taiwanese constitutional development, I am heavily indebted to Jiunn-rong Yeh, The Constitution of Tainan: A Contextual Analysis (2016). Any errors are my own.
} 
Chinese Communist Party-it would be difficult to characterize it yet as the Constitution of Taiwan. There was no clearly identified Taiwanese people as a political entity, and there had been no attempt, nor even claimed attempt, to make a constitution for or on behalf of such a people. The document had aspired to be a constitution for the entirety of China.

For more than forty years, Taiwan was a dictatorship. The suppression of democracy and the lack of respect for civil rights were similar to other dictatorships around the world. However, the territorial anomaly of a government on Taiwan claiming but not exercising authority over mainland China provided a distinctive dimension. There was a particular difficulty in that members had been elected to two branches of Government, the Legislative Yuan and the Control Yuan, from districts throughout China but there could now be no elections to replace them. In 1954, the Constitutional Court, the Judicial Yuan, held that existing members of the Legislative Yuan should keep their seats until they could be replaced, as otherwise the system of government would cease to function. ${ }^{52}$ This ensured not only that new legislators could not be elected but also that existing legislators would continue to be representatives of areas that would not be affected by the laws they passed. Conversely, those who would be affected-the residents of Taiwanremained significantly underrepresented. The same result effectively applied to the National Assembly, the body responsible for electing the President and Vice-President as well as amending the Constitution. Although Article 28.1 required that delegates be elected every six years, Article 28.2 required the term of office of each delegate to terminate on the day the next National Assembly convened. As there had been no elections, there could be no new Assembly and the term of the first elected delegates continued indefinitely.

In the early 1990s, several measures were adopted that led to increased democracy within Taiwan, in a way that contributed to the evolution of a Taiwanese Constitution. In 1990, the Constitutional Court reconsidered its interpretation of 1954. The Court held that while the 1954 Interpretation had been necessary, it had not been the Court's intent to ensure lifelong tenure for representatives. ${ }^{53}$ The Court reasoned that the periodic election of representatives was an essential avenue for the reflection of the will of the people and the implementation of constitutional democracy. In relation to the National Assembly, the Court held that Article 28.2 was designed to ensure continuity and could not derogate from the core obligation in Article 28.1 to hold elections every six years. The Court directed that those first-term representatives who had not been subject to periodic reelection would stand down by the end of 1991. It noted that the constitutional provisions for nationwide elections were not fully applicable (since elections could not be held in mainland China). The Court required the Government to make an appropriate plan for a new electoral system. Given the inability to conduct elections in mainland China, democratic reform would necessarily facilitate the emergence of a new constitutional system by aligning the interests and identity of those who made the laws with the interests and identity of those subject to the laws.

There followed a series of seven constitutional reforms from 1991 to 2005 . Through the initial reforms, the National Assembly took various steps that more closely aligned constitutional actors in Taiwan with the people of Taiwan. Over time, however, the role of the National Assembly itself in constitutional amendment became a key focus. In the first phase of additional articles, Articles 1 to 3 reallocated the seats in the representative branches of government-National Assembly, Legislative Yuan, and Control Yuan. As well as direct elections from constituencies in Taiwan, there would be a nationwide constituency that would include citizens residing abroad. In the second phase of constitutional reform, the method of election of President and Vice President was changed to election by the electorate in the free area of the Republic of China. The next phase of revision specified that the method of election would involve direct election by the entire populace of the free area of the Republic of China. These references to "the free area of the Republic of China" effectively meant

\footnotetext{
${ }^{52}$ Judicial Yuan Interpretation 31, https://www.judicial.gov.tw/constitutionalcourt/en/p03_01.asp? expno=31.

${ }^{53}$ Judicial Yuan Interpretation 236, https://www.judicial.gov.tw/constitutionalcourt/en/p03_01.asp?expno=261.
} 
Taiwan and were the key move in specifying a political community within narrower bounds than the territory claimed by the Constitution, a point to which I will return below.

The fifth, sixth, and seventh rounds of constitutional revisions were directed at the role of the National Assembly. The National Assembly survived the fifth and sixth rounds of revisions, although its powers and autonomy were reduced. The Constitutional Court, adopting a doctrine of unconstitutional constitutional amendments, declared the fifth round of revisions unconstitutional. The sixth round reduced the role of the National Assembly to meeting only if the Legislative Yuan proposed a constitutional referendum.

The seventh round of revisions abolished the National Assembly and introduced a referendum process for constitutional amendment. This is the final set of constitutional revisions that has led to a complete set of twelve Additional Articles, superseding but largely encompassing the revisions made since 1991. Constitutional amendment is dealt with in Additional Articles 1, 4, and 12. The Legislative Yuan must initiate any proposal to amend the Constitution or alter the national territory. One quarter of the total members of the Legislative Yuan must propose the amendment or alteration. The amendment or alteration must then be approved by three quarters of those members of the Legislative Yuan present at a meeting attended by at least three quarters of the total members of the Legislative Yuan. If the proposal passes these hurdles, it can then be put to the people in a referendum, after a period of between six and nine months. For the proposal to be approved, an absolute majority of the electorate in the free area of the Republic of China must vote in favor of it.

These are onerous amendment requirements. Indeed, Yeh speculates that they will make future constitutional revisions "extremely difficult, if not impossible." ${ }^{4}$ Yeh, however, also offers the following conclusion: "[T] he power to revise the Constitution-a most symbolic power of constitutional government - is now returned to the people. Without majority approval, no further constitutional change can be made. For the first time in history, public sovereignty truly resides in the Taiwanese people." ${ }^{55}$ Given Yeh's views on the difficulty of the amendment process, he cannot mean that the people of Taiwan have gained the power to change the Constitution. They are not sovereign in that sense. But it remains significant that the people of Taiwan have acquired the ultimate veto power over constitutional changes. This orients the Constitution towards serving the common good of the Taiwanese people, rather than the inhabitants of China as a whole.

This orientation to the people of Taiwan sits somewhat uneasily with the Constitution's continuing claim to the entire territory of China as broadly understood. Article 4 of the Constitution, as approved in 1946, provided, "the territory of the Republic of China within its existing national boundaries shall not be altered except by a resolution of the National Assembly."

This provision crystallizes the boundaries of the national territory at the moment of constitutional enactment. The ban on alteration of the existing boundaries, other than by resolution of the National Assembly, appears to prohibit any interpretation that the phrase "existing boundaries" has an ambulatory effect, allowing the constitutional definition of boundaries to catch up with any de facto change to those boundaries. Rather, unless altered in the stipulated way, the boundaries remain fixed at their 1946 extent. The precise delineation of the "existing boundaries" in 1946 is somewhat contestable. For instance, despite having effectively lost control of Mongolia following the fall of the Qing Dynasty in 1911, the Republic of China continued to assert its entitlement to rule Mongolia, vetoing Mongolia's admission to the United Nations until the 1960s.

Following the withdrawal of the KMT to Taiwan, the territorial claim in Article 4 was the faultline of the most foundational issue in Taiwanese and Chinese politics: had a separate state come into existence on the territory of Taiwan, or were there two rival regimes making claim to the one China? In this context, enterprising litigants in 1993 sought an interpretation of the Judicial Yuan on the meaning of Article 4 of the Constitution. Specifically, they challenged the continued

\footnotetext{
${ }^{54} \mathrm{YEH}$, supra note 51 , at 48.

${ }^{55} I d$.
} 
existence of a Department of Mongolian Affairs in the Government in Taiwan. The Judicial Yuan avoided the issue, holding that the delimitation of national territory was a political question beyond the bounds of judicial review. ${ }^{56}$ The Additional Provisions of 2005 do not change Article 4, but they do change the process for altering the national territory, removing the responsibility from the National Assembly, now abolished, and instead applying the general amendment procedure, described above. This makes it difficult to foresee any change to the national territory through the formal amendment process.

These constitutional changes were a response to public protests, negotiations between the KMT and the opposition DPP and were to some extent facilitated by divisions within the KMT itself. ${ }^{57}$ This story of constitutional development shows how a constitution can come into existence without any exercise of constituent power. The process of pressure, negotiation, elite division and concession did not amount to the spontaneous emergence of a people of Taiwan. More important, there was no attempt to exercise constituent power in the sense of unlawfully replacing the preexisting constitution. Rather, all changes were made through the existing amendment process. Nevertheless, what now exists is a new constitution. The Republic of China Constitution has become the Constitution of Taiwan in effect, if not in name, through a series of constitutional amendments that oriented the Constitution towards serving the needs of those subject to it. As Richard Albert argues, amendment rules are the most important part of a constitution. ${ }^{58}$ Albert has also drawn attention to the expressive function of amendment rules. ${ }^{59}$ The effect of the amendments in Taiwan were to replace one constitutional legislator with another. They are equivalent to the patriation of the Canadian Constitution that occurred in 1982 when the Westminster Parliament relinquished its power of amendment and accorded this to Canadian political actors. ${ }^{60}$ This is such a fundamental change as to justify the proposition that what exists is now a new constitution of Taiwan, rather than simply an amended constitution of the Republic of China.

The people of Taiwan did not will themselves into existence in a momentary exercise of constituent might; rather, they came into existence as a result of (or were recognized by) a series of legal changes designed to adapt the constitutional reality to the political reality. The constitutional amendments have constructed a people of Taiwan, the electors of the Free Area of the Republic of China, as the focus of constitutional concern, both through the electoral system and the provisions on constitutional and territorial change. Notwithstanding the constitutional claim to the territory of China within its 1946 boundaries, the actual territory of the constitutional system is Taiwan and its surrounding islands. This is neither unusual nor conceptually problematic. The territory of a constitutional system reflects a geographically bounded convention of rule-application by officials; master-text constitutions, however, may make expressive claims to territory that they do not control. ${ }^{61}$ Exercises of constituent might are one way of breaking those conventions in order to establish a new constitutional system with a different territorial scope. But this is not how Taiwan acquired its Constitution.

\section{G. Ireland: exercise of constituent power as political non-event}

The exercise of constituent power conjures up images of real or symbolic violence: one constitutional order is unlawfully replaced by another in a big-bang moment of legal self-authorization.

\footnotetext{
${ }^{56}$ Judicial Yuan Interpretation 328, https://www.judicial.gov.tw/constitutionalcourt/en/p03_01.asp? expno=328.

${ }^{57}$ For a general account of the early part of this period, see Shelley Rigger, Machine Politics and Protracted Transition in Taiwan, 7 Democratization 135 (2000).

${ }^{58}$ Richard Albert, Amending Constitutional Amendment Rules, 13 INT. J. Const. L. 655 (2015).

${ }^{59}$ Richard Albert, The Expressive Function of Amendment Rules, 59 MCGILL L.J. 225 (2013).

${ }^{60}$ See Oran Doyle, Constitutional Transitions, Abusive Constitutionalism and Conventional Constraint, 35 NAT. J. CONST. L. 67 (2017).

${ }^{61}$ Oran Doyle, The Silent Constitution of Territory, 16 INT'L. J. Const. L. 887 (2018).
} 
Although the 1937 Irish Constitution commences with the assertion of such self-authorization, "We, the people of [Ireland] ... adopt, enact and give to ourselves this Constitution," 62 a closer examination tells a rather different story. The reference to popular enactment was accurate, insofar as such claims ever can be. The Constitution was enacted by a plebiscite that was authorized by an unconstitutional statute, in a deliberate rupture of any chain of legal validity with the existing constitutional order. It was also a rupture with previous ideas of the Irish nation: the people entitled to vote in the plebiscite and to whom the Constitution would first apply were located on only part of the island of Ireland, representing a significant retrenchment on claims of an all-island Irish identity. Unlike the situation of Taiwan, therefore, the enactment of the 1937 Constitution can plausibly be presented in terms of constituent power. I shall argue, however, that this must be understood in terms of an Irish people momentarily exercising constituent power in 1937, rather than an Irish people creating itself as a constituent power in 1937 and then diachronically subsisting the new Constitution.

For much of its history, the constitutional story of Ireland had been one of English influence and control. In 1800, Acts of Union were approved by the Irish Parliament in Dublin and by the Westminster Parliament. Despite the Union, Ireland remained a separate, restive part of the United Kingdom. Irish representatives had 100 seats in the House of Commons at Westminster and used this power to advance the cause of limited self-government for Ireland, known as "home rule." Home rule, however, was strongly opposed by unionists in the northeast of Ireland. The religious-demographic makeup of this part of Ireland was markedly different, reflecting the success of plantations in Ulster of British Protestants some 250 years previously. ${ }^{63}$ At the start of World War I, the Liberal Government forced through legislation to grant home rule to Ireland with no exception for Ulster, but suspended its operation until the end of the War. After a foiled insurrection in 1916, nationalist opinion in Ireland hardened and sought complete independence rather than home rule. A war of independence was fought from 1919 to 1921, culminating in the Anglo-Irish Treaty, which conceded Dominion Status, equivalent to Canada, for twenty-six counties of Ireland, while two thirds of Ulster remained part of the United Kingdom. Dominion Status involved the maintenance of several constitutional connections between what was now called "the Irish Free State" and the United Kingdom, as well as a continuing claim by Westminster that it was competent to legislate for the Irish Free State, implicitly including withdrawal of Dominion Status.

In 1922, the electorate of the Irish Free State elected a constituent assembly that adopted the Constitution of the Irish Free State Act 1922.64 The Westminster Parliament then enacted the Irish Free State Constitution Act 1922, including as a schedule the entirety of the Irish Act and Constitution. The Irish Act entrenched and made unamendable the provisions of the AngloIrish Treaty, effectively guaranteeing those constitutional connections with the United Kingdom. Otherwise, Article 50 of the Constitution provided that constitutional amendments could be made by referendum, requiring an absolute majority of all those registered to vote. It also, however, allowed for amendments to be made by ordinary legislation for a period of eight years. Before that eight-year period elapsed, the Parliament extended it a further eight years. This enabled the Parliament effectively to sidestep all constitutional restraints, but the power was also used after 1932 to dismantle the remaining constitutional connections with the United Kingdom. In State (Ryan) v. Lennon, the Supreme Court in 1934 cast doubt on the legitimacy of this constitutional dismantling, observing that the Constitution had been made by a constituent assembly and, therefore, the constraints on amending the constitutional relationship with the United Kingdom could

\footnotetext{
${ }^{62}$ Constitution of Ireland 1937 pmbl. In this Section, I draw on Oran Doyle, The Constitution Of Ireland: A Contextual Analysis (2018).

${ }^{63}$ Jonathan Bardon, A History of Ulster ch. 5 (2d ed. 2001).

${ }^{64}$ This method of enactment followed the approach adopted for most other European constitutions adopted between 1919 and 1921: those in Germany, Czechoslovakia, Estonia, Austria, Poland and the Kingdom of the Serbs, Croats and Slovenes. See Donal K Coffey, Constitutionalism in Ireland 1932-1938: National, Commonwealth, and International Perspectives ch. 4 (2018).
} 
not be set aside by the ordinary amending power. ${ }^{65}$ By 1936, however, Ireland had acquired a much greater degree of independence than had been the case in 1922. The Irish Free State Constitution, however, was not functioning properly. It was tainted by its dubious parentage-was it an Act of the Westminster Parliament or an Irish Constituent Assembly? It failed to hold the Parliament to fundamental rights standards, and it arguably delegitimized the process of dismantling Ireland's constitutional connections with the United Kingdom.

It was in this context that Éamon de Valera, Prime Minister and dominant political figure of the era, decided to draft a new Constitution. This was approved by the existing Parliament and put to the people in the plebiscite described above. As noted above, this was a rupture with both the existing constitution and previous notions of the Irish people. The enactment of the new Constitution, however, attracts relatively little attention, whether in general, as distinct from legal, history books or the popular imagination. It is not seen as a foundational event. Although the Constitution was approved by a narrow majority of fifty-six percent to forty-four percent, reflecting partisan animosity from the division over the Anglo-Irish Treaty, there was no suggestion that it was illegitimate.

The muted reaction to the 1937 Constitution suggests that this was not a big-bang event in which a constituent power willed itself into existence, but rather the momentary exercise of constituent power by an entity for which the ground had been laid by the existing constitutional system. In my view, the fifteen-year existence of the Irish Free State had legitimized the exercise of constituent power by the people of that state. The identity of the Irish people in the 1937 Constitution was a product of the laws and constitutional order that they would ultimately replace with a new constitution in that momentary exercise of constituent power. In this way, the perception of an entity as a legitimate potential bearer of constituent authority can assist that entity to exercise constituent might: others are more likely to acquiesce in what they perceive to be legitimate. The people of Ireland exercised constituent power in making the 1937 Constitution, but this means simply that they unlawfully set aside the existing constitution to make a new constitution. Exercises of constituent power need not be experienced as quasi-revolutionary acts by entities that stand wholly outside the legal system. On the contrary, an existing legal system can pave the way towards its own unlawful replacement. The entity that exercises constituent power can be partially or largely a legal construct, although it need not be so. What distinguishes the exercise of constituent power is simply the unlawful replacement of one constitution with another, no more and no less.

This process of legally shaping the identity of the Irish people continued under the 1937 Constitution. Legal changes to voting entitlements ${ }^{66}$ and citizenship rules $^{67}$ arguably shifted the identity of the Irish people, but more significant changes occurred in 1998. The bearer of constituent power in 1937 had been the people of southern Ireland, but it made a territorial claim to the entire island of Ireland that implicitly positioned that enacting people as the ad hoc representatives of a broader all-island Irish people. This synechdocic maneuver was altered by the 1998 Amendments that gave effect to the Northern Ireland peace settlement. The most significant were changes that sought to diminish the importance of territory and national identity in a number of ways. Article 2, which previously claimed the entire island of Ireland, now recognizes the birthright of all people born on the island of Ireland to be part of the Irish nation. Article 3 subtly rejects ideas of a unitary people in favor of a project that works for individual, autonomous persons. The aim is to "unite all the people" who share the territory rather than to make a claim to a territory on behalf of a people.

\footnotetext{
${ }^{65}$ State (Ryan) v. Lennon [1935] IR 170 (Ir.). The Privy Council in London reached the opposite conclusion. In its view, the Irish Free State Constitution had been made by an Act of the Westminster Parliament and, therefore, could now be amended by the Irish Parliament, by reason of the Statute of Westminster 1931. Moore v. Att'y Gen. [1935] IR 73 (Ir.).

${ }^{66}$ The Constitution was amended in 1972 to reduce the voting age to eighteen.

${ }^{67}$ The Constitution was amended in 2004 to remove a ius soli entitlement to citizenship.
} 
This process of legal change is difficult to make sense of if we treat the constituent power as a diachronic entity that exists outside the constitutional order. On the basis of Schmittian theory, it should not be within the scope of a constituted power to alter the identity of the constituent power. Perhaps it could be argued that the Amendments caused a divergence between the Irish people and the constituent power, but this would be inconsistent with the claim that the constituent power must be the people. Perhaps there is a divergence between the Irish people as constitutional actor and the Irish people for constituent power purposes. This is essentially the move we considered in Section D that distinguishes between the primary constituent power and the secondary constituent power. But it illustrates the artificiality of that approach. We must imagine three fictive entities, with largely overlapping membership: (a) the people, (b) the people as primary constituent power, and (c) the people as secondary constituent power. We should avoid the creation of fictive entities unless absolutely necessary. The people may be a conceptually necessary actor if we are to make sense of constitutional arrangements, but we do not need a primary constituent power and secondary constituent power as well.

The more parsimonious explanation is simply to drop the pretense that the constituent power is an entity. In 1937, the people of Ireland, largely identified by the preexisting constitutional system, exercised a constituent power to create a new constitution. The character of the power as "constituent" flows simply from the fact that it unlawfully constituted a new constitutional order. The law, possibly along with other factors, continued to shape the identity of the Irish people. In 1998, they exercised the constituted amendment power to achieve a more significant change in their own identity. This exercise of the amendment power was legitimate, notwithstanding that it altered the most fundamental decisions of 1937 (a) because it fell within the scope of the amendment power that had been conferred in 1937, and (b) because there is no moral basis on which to impugn this redefinition of Irish popular identity.

\section{H. Implications for populist constitutionalism}

This Article develops a theory that consistently treats constituent power as a capacity rather than an entity. Rather than assume a constituent power as a diachronic entity or insist that only one entity, the people, can exercise constituent power, it is better to understand constituent power as a capacity that is exercised by any entity when it successfully creates a new constitution by breaching an existing constitution. This theoretical account better fits actual experiences of constitutionmaking. The Irish example shows how the people that creates constitutions is not necessarily a pre-legal or extra-legal actor but instead can be legally constructed. If we insist that the people as constituent actor is a diachronic entity, we encounter difficulties explaining future acts of constitution-making - for instance by a different people partly located in the same territory-as well as constitutions that grant the people a role in constitutional amendment. The Taiwanese example illustrates that constitutions can be created without any exercise of constituent power but directs our attention to the way in which legal changes can reorient an existing constitution towards a new people.

Some account of constituent power is important within constitutional theory as a means of explaining how constitutions can be created without any pre-existing constitutional authority to do so. Treating constituent power as a capacity, however, is preferable for a number of reasons. First, it avoids the unnecessary creation of fictive entities described above. We can accept the existence of the people as a real actor potentially relevant to constitutions, without having to create parallel entities of the constituent power, still less a primary constituent power and secondary constituent power. There is no evidence for the existence of these fictive entities, except when they are performing specific constitutional functions, whether creation or amendment. But constituent power as capacity provides an adequate explanation of those functions without needing to assume any additional entities. For that reason alone, it is a preferable account of constituent power. 
Second, once constituent power is understood as an entity, it almost inevitably becomes seen as a diachronic entity. This diachronicity is the most challenging element of the constituent power's ontology. In what sense does the constituent power exist when it is not doing anything? Diachronicity makes the identity of the constituent power critical: the constituent power in the future must be the same as the constituent power in the past. This removes one of the initial attractions of constituent power theory, its ability to conceptualize the unlawful reorganization of the world into different constitutional orders. If the existing people is the constituent power, how can a new people occupying a smaller or overlapping geographic entity ever be a constituent power? There cannot be two constituent powers simultaneously in the same geographic area. In short, if we treat the constituent power as an entity, we lose the ability to explain the creation of new constitutional orders.

Third, focus on constituent power as capacity directs our attention to the ambiguity between brute-force power (might) and moral power (legitimate authority). This compels us to construct a moral theory about how constituent might can amount to legitimate constituent authority. Law can only fulfil its role of serving the common good if the world is subdivided into discrete constitutional orders, there as yet being no prospect of a global constitution. Constituent might is one way-although, as Taiwan demonstrates, not the only way-in which this can be achieved. Where constituent might is successfully exercised it can amount to legitimate constituent authority, simply because it has served the common good by establishing a functioning constitutional order. Given that existing constitutional orders already serve this common good function to some extent, the replacement of a constitutional order can be justified only on the basis of whether it is better than the order that it replaces, all things considered. Constitutional orders should be oriented to serving the needs of those subject to them and evaluated on this basis.

All of this has significant implications for populist constitutionalism. As we saw in Section C, populist constitutionalism makes three claims. ${ }^{68}$ First, the people exist as a constituent power prior to and independently of the constitution: the populist therefore values the will of the people over constitutional rules. Second, populists understand popular sovereignty as the presence of the people in quotidian politics with a common interest and will: this leads to a distrust of politicians and representation, perhaps with a preference for referendums as a direct expression of the popular voice. Third, constitutional identity turns on a people with a fixed identity, traceable through time.

This Article's account of constituent power removes the underpinnings of these claims. The people do not exist as a constituent power but may sometimes exercise constituent power. Even where a constitution can reasonably be said to have been made by the people, this does not mean that only the people can exercise constituent power in the future. The identity of the people is not fixed but is open to change through ordinary legal processes and other ways. The people that exercises constituent power does not cease to exist immediately after exercising that power, but they do not subsist as a constituent power with special constitutional authority. The claim that the people are necessarily an actor with particular authority in quotidian politics cannot be based on the theory of constituent power.

The people's irrelevance as a source of continuing constitutional authority does not, however, mean that constitutional references to the people are irrelevant. We saw above that constituent might can amount to legitimate constituent authority because of the common good imperative to establish discrete constitutional systems. Constituent power exercised in the name of the people emphasizes the proper orientation of constitutions: they must serve the common good of a particular people. What is truly significant in the Preambles cited above, therefore, is not so much the claim that the people made the constitution in question but rather the claim that it was made for the people. As such the claims of popular enactment are relevant irrespective of whether the constitution in question was in any real sense made by the people. They set the framework for consideration of the common good. The constitutional system is answerable to the needs

${ }^{68}$ Corrias, supra note 5 , at $9-14$. 
of all the inhabitants of the territory, not just an elite subset or a narrowly partisan majority. A popular constitutional democracy is not only electorally accountable and legally constrained government but is also oriented towards serving the common good of a particular people: the identity of that people is important. A popular constitutional democracy can emerge otherwise than through the exercise of constituent power by the people. The Additional Articles to the Republic of China Constitution cumulatively transformed it into a constitution for the people of Taiwan, without that people ever having exercised constituent power.

Could this account of constituent power provide support for populist argumentation in a different way? Might a populist argue that the people should exercise constituent power now to replace the existing constitution with a new one? In short, yes. Such an argument is not necessarily populist, but it is open to populists. And it would be justified if it were truly the case that the benefits of the new constitution would outweigh the risks of replacing the existing constitution.

My account of constituent power does provide some support for what might be characterized more distinctively as populist argumentation. A political community that serves the interests of economic, social, or political elites - whether national, supranational or international-fails to serve the common good of the people. ${ }^{69}$ Of course, such a state-of-affairs does not present itself in a pre-labelled, non-contestable box. There are strong arguments, for example, that participation in supranational institutions can serve the interests of national political communities. There is always a risk, however, that they will not and this, rather than any supranational set of values, remains the litmus test of their justifiability. ${ }^{70}$ As Gonzalo Candia argues in his Article in this volume, even a supranational entity that takes steps genuinely intended to assist democracy in the national polity can fuel the populist rhetoric based on the friend-foe distinction. ${ }^{71}$ The populist leader can sharpen the definition of the national people and her identification with them, in opposition to the elite, supranational other. While this possibility should affect the prudential decision of a supranational entity on whether to intervene, it does not directly affect the legitimacy of such interventions.

To take another example, a populist claim that government has failed adequately to protect the laboring classes from economic dislocation ${ }^{72}$ can draw support from the account of popular constitutional democracy advanced in this Article. In his contribution to this volume, Zoran Oklopcic shows how the "anti-populist conjurers of populism" fail to pay equally serious attention to the reality of elite groups and actors against whom the supposed populists respond. ${ }^{73}$ The account of populist constitutionalism that I elaborate in this Article would take the existence of such elites as a serious threat to constitutionalism.

This understanding of popular constitutional democracy checks some strands of populist argumentation. The requirement to serve the common good of the people mandates greater inclusivity, not less. All those who are subject to the constitutional order are entitled to have their interests taken genuinely into account. A narrow electoral majority-still less an electoral plurality-is not the people. Any attempt to govern for a narrow but pure people is an affront to popular constitutional democracy.

This conclusion is fully consistent with my claim that the constituent power does not exist as a diachronic entity. The people can exist through time without also being a constituent power, or simultaneously a primary constituent power and secondary constituent power. Although a

\footnotetext{
${ }^{69}$ On populist anti-cosmopolitanism, see Mark Tushnet, Comparing Right-Wing and Left-Wing Populism, in CONST. DEM. IN CRIsIs 639, 647-648 (Mark A. Graber, Sanford Levinson \& Mark Tushnet eds., 2018).

${ }^{70}$ I suggest this is the correct basis on which to evaluate the jurisprudence of supranational courts that is the subject of Andrea Pin's article in this volume. Andrea Pin, The Transnational Drivers of Populist Backlash in Europe: The Role of Courts, in this issue.

${ }^{71}$ Gonzalo Candia, Regional Human Rights Institutions Struggling Against Populism: The Case of Venezuela, in this issue.

${ }^{72}$ Issacharoff, supra note 1 , at 446-47.

${ }^{73}$ Zoran Oklopcic, Imagined Ideologies: Populist Incarnations, Liberalist Projections, and the Horizons of Constitutionalism, in this issue.
} 
constitution made for a people must serve the interests of that people, it does not fix the popular identity for all time. The contemporary people, for good or ill, remain in control of their own identity and may deploy constitutional and other means to adjust their identity. Whatever their identity becomes, their constitution remains oriented to serving their interests.

\section{Conclusion}

Mainstream theories of constituent power-perhaps inadvertently-provide intellectual support for the peripheral theories of populist constitutionalism and-by extension-for populist argumentation in quotidian politics. Treating the constituent power as a fictive entity that persists through time leads us into a conceptual morass that obscures the character of the people and the role they play in a popular constitutional democracy. There is no constituent power with a fixed diachronic identity that is a continuing source of constitutional authority. Constituent power is not an entity, but a capacity: the ability unlawfully to replace one constitutional system with another. The people are but one of a number of entities that could exercise constituent power. Furthermore, constitutions can come into existence without any exercise of constituent power.

Where constituent might is successfully exercised, this can amount to legitimate constituent authority, even though unlawful. The fact that the people exercised constituent power to create a constitution, however, does not determine how the constitution may be amended or who may exercise constituent power in the future. Although particular constitutional orders may afford specific roles to the people-for instance in relation to constitutional amendment - the people that made the constitution do not subsist as a constitutional actor with overarching authority. Over time, the identity of the people may shift, whether through legal changes or other social forces or by some combination of the two. The true relevance of constitutional invocations of the people lies not in any authorization of constituent power but rather in orienting the constitutional system towards meeting the needs of a particular people. This understanding of the role of the people undercuts much populist argumentation while emphasizing the imperative for a constitutional order to serve the common good of the people that are subject to it.

Given the prevalence of constitutional references to the people, constitutional theory cannot avoid an account of the people's role in constitutional democracies. Mainstream constitutional theory, however, has developed an account of people as constituent power that is deeply unconvincing. This account moreover lends inadvertent support to pernicious forms of populist argumentation. It would be naïve to think that developments in constitutional theory will have any direct effect on populist politics, the drivers of which are multi-faceted. Nevertheless, constitutional theorists have a particular responsibility and opportunity to address the constitutional rhetoric of populists. Without a convincing and coherent account of the role of the people in popular constitutional democracies, we can scarcely even begin.

Cite this article: Doyle O (2019). Populist constitutionalism and constituent power. German Law Journal 20, 161-180. https:// doi.org/10.1017/glj.2019.11 